\title{
Pemodelan Harga Beras di Pulau Sumatera dengan Menggunakan Model Generalized Space Time ARIMA
}

\author{
Dwi Yulianti*, I Made Sumertajaya*, Itasia Dina Sulvianti* \\ *Departemen Statistika Institut Pertanian Bogor
}

\begin{abstract}
Abstrak-Model generalized space time autoregressive integrated moving average (GSTARIMA) merupakan model data deret waktu peubah ganda yang mempunyai ketergantungan lokasi dan waktu (space time). Model ini merupakan pengembangan dari model space time autoregressive integrated moving average (STARIMA) dengan asumsi parameter-parameter model berbeda untuk setiap lokasi sehingga model GSTARIMA lebih fleksibel dibandingkan model STARIMA. Tujuan penelitian ini yaitu menentukan model terbaik dan meramalkan harga beras pada seluruh ibukota provinsi di Pulau Sumatera dengan menggunakan model GSTARIMA. Data yang digunakan adalah data mingguan harga beras di seluruh ibukota provinsi di Pulau Sumatera pada Januari 2010 hingga Desember 2017. Pembobot yang digunakan dalam penelitian ini yaitu pembobot kebalikan jarak dan pembobot queen contiguity. Hasil pemodelan menunjukkan bahwa model terbaik adalah model GSTARIMA $(1,1,0)$ dengan matriks pembobot queen contiguity yang mempunyai nilai mean absolute percentage error (MAPE) yang terkecil yaitu sebesar $1.17817 \%$.
\end{abstract}

Kata kunci-GSTARIMA; kebalikan jarak; MAPE; queen contiguity; space time;

\section{PENDAHULUAN}

\section{A. Latar Belakang}

Indonesia merupakan negara agraris yang sebagian besar penduduknya mengonsumsi beras sebagai sumber makanan pokok. Rata-rata konsumsi beras nasional terus mengalami peningkatan sejak 4 tahun terakhir. Konsumsi beras di Indonesia perkapita pertahun mencapai $86 \mathrm{~kg}$ (BPS 2017). Tingginya konsumsi beras tidak disertai dengan peningkatan luas lahan pertanian, sehingga hal tersebut mengakibatkan semakin menurunnya ketersediaan beras di Indonesia. Permasalahan ketersediaan beras akan berdampak terhadap kestabilan harga beras di Indonesia. Harga beras yang tidak stabil menjadi perhatian utama, karena berdampak terhadap perkembangan inflasi di Indonesia. Beras merupakan salah satu komoditas pangan yang memiliki pengaruh yang cukup besar terhadap inflasi baik nasional maupun regional (Muljawan and Alibaba (2009)). Hal tersebut menjadikan beras sebagai salah satu komoditas bahan pangan yang memiliki arti strategis, karena berbagai gejolak yang terjadi pada suatu komoditas ini akan berdampak luas terhadap perekonomian negara Indonesia (Noviar (2013)).

Sebagian besar provinsi di Pulau Sumatera merupakan provinsi yang menghasilkan produksi beras terbesar di Indonesia setelah provinsi Jawa Timur, Jawa Barat, dan Jawa Tengah (BPS (2017)). Akan tetapi, tidak semua provinsi di Pulau Sumatera terpenuhi akan kebutuhan beras, karena berdasarkan diskusi yang digugus Kedeputian II KSP bersama Kementerian Pertanian, Perum BULOG, BUMN PT Pertani, perwakilan petani dan pelaku industri pada tahun 2015 mengungkapkan bahwa terdapat 15 provinsi di Indonesia yang mengalami defisit beras dan dua diantaranya adalah provinsi Riau dan Jambi yang lokasinya berada di Pulau Sumatera. Provinsi Sumatera lainnya yang mengalami surplus beras menjadi pemasok bagi daerah yang mengalami defisit beras di Pulau Sumatera. Hal tersebut mengakibatkan terjadinya kesenjangan harga beras antar provinsi di Pulau Sumatera serta mengindikasikan harga beras di Pulau Sumatera memiliki ketergantungan spasial, sehingga mengakibatkan tidak stabilnya harga beras. Harga beras yang tidak stabil memiliki unsur ketergantungan waktu, karena dipengaruhi oleh harga beras pada waktu-waktu sebelumnya dan juga dipengaruhi oleh ketersediaan stok beras di suatu lokasi sehingga terdapat ketergantungan spasial (Yusrina et al. (2017)). Perlu 
adanya strategi kebijakan dari pemerintah, terutama pemerintah daerah provinsi di Pulau Sumatera untuk mencegah kemungkinan masalah yang ditimbulkan oleh harga beras yang tidak stabil sehingga memerlukan beberapa metode yang tepat untuk menangani permasalahan tersebut.

Pemodelan data peubah ganda yang melibatkan lokasi dan waktu pada suatu data deret waktu adalah model space time. Salah satu model space time adalah space time autoregressive integrated moving average (STARIMA). Model STARIMA pertama kali diperkenalkan oleh (Pfeifer and Deutsch (1980)). Model ini memiliki keterbatasan dalam menangkap keheterogenan karakteristik masingmasing lokasi sehingga memiliki nilai parameter yang sama untuk lag waktu yang sama, namun berbeda lokasi. Model yang menggabungkan interdependensi waktu dan lokasi dengan parameter yang berbeda untuk setiap lokasi adalah model GSTARIMA (generalized space time autoregressive integrated moving average) (Min et al. (2010)). (Siregar (2015)) menggunakan model STARIMA dan GSTARIMA dalam pemodelan dan peramalan harga gula pasir pada delapan ibukota provinsi di Pulau Sumatera dengan menghasilkan pembobot terbaik pada model STARIMA adalah kebalikan jarak dan pada model GSTARIMA adalah normalisasi korelasi silang. (Daraputri (2015)) menggunakan model generalized space time pada pemodelan harga gula pasir di Pulau Sumatera dengan menghasilkan model terbaiknya adalah model GSTAR dengan pembobot queen contiguity. Pembobot mencirikan adanya pengaruh interaksi spasial/lokasi. Penentuan pembobot lokasi yang tepat sangat bergantung pada fenomena yang dimodelkan.

Data harga beras di Pulau Sumatera merupakan data deret waktu peubah ganda yang dipengaruhi oleh efek spasial. Penelitian ini menggunakan model GSTARIMA dengan dua matriks pembobot yang digunakan yaitu pembobot kebalikan jarak dan pembobot queen contiguity.

\section{B. Tujuan}

Tujuan dari Penelitian ini, yaitu:

1) Menentukan model GSTARIMA yang terbaik pada data harga beras di Pulau Sumatera.
2) Meramalkan harga beras pada seluruh ibukota provinsi di Pulau Sumatera menggunakan model GSTARIMA yang terbaik.

\section{METODOLOGI}

\section{A. Data}

Data yang digunakan dalam penelitian ini adalah data yang didapatkan dari Kementerian Pertanian Republik Indonesia. Penelitian ini menggunakan data harga beras mingguan pada seluruh ibukota provinsi di Pulau Sumatera yang meliputi provinsi Aceh, Sumatera Utara, Sumatera Barat, Riau, Jambi, Bengkulu, Sumatera Selatan, Lampung, Bangka Belitung, dan Kepulauan Riau. Data harga beras mingguan diambil dari minggu pertama bulan Januari 2010 hingga minggu terakhir bulan Desember 2017.

Tabel I

PEUbah YANG DigunAKAN DALAM PENELITIAN

\begin{tabular}{|c|c|c|c|}
\hline Peubah & Keterangan & Tipe peubah & Satuan \\
\hline $\mathrm{Z} 1$ & Harga beras Provinsi NAD & Numerik & Rupiah \\
\hline $\mathrm{Z} 2$ & $\begin{array}{l}\text { Harga beras Provinsi } \\
\text { Sumatera Utara }\end{array}$ & Numerik & Rupiah \\
\hline $\mathrm{Z} 3$ & $\begin{array}{l}\text { Harga beras Provinsi } \\
\text { Sumatera Barat }\end{array}$ & Numerik & Rupiah \\
\hline $\mathrm{Z} 4$ & Harga beras Provinsi Riau & Numerik & Rupiah \\
\hline $\mathrm{Z} 5$ & Harga beras Provinsi Jambi & Numerik & Rupiah \\
\hline Z6 & $\begin{array}{l}\text { Harga beras Provinsi } \\
\text { Bengkulu }\end{array}$ & Numerik & Rupiah \\
\hline $\mathrm{Z7}$ & $\begin{array}{l}\text { Harga beras Provinsi } \\
\text { Sumatera Selatan }\end{array}$ & Numerik & Rupiah \\
\hline $\mathrm{Z} 8$ & $\begin{array}{l}\text { Harga beras Provinsi } \\
\text { Lampung }\end{array}$ & Numerik & Rupiah \\
\hline Z9 & $\begin{array}{l}\text { Harga beras Provinsi } \\
\text { Bangka Belitung }\end{array}$ & Numerik & Rupiah \\
\hline $\mathrm{Z} 10$ & $\begin{array}{l}\text { Harga beras Provinsi } \\
\text { Kepulauan Riau }\end{array}$ & Numerik & Rupiah \\
\hline
\end{tabular}

\section{B. Prosedur Analisis Data}

Metode penelitian ini dilakukan melalui beberapa tahapan, yaitu :

1) Pengambilan data

Data harga beras dibagi menjadi dua bagian yaitu, 421 data untuk pendugaan model dan 12 data untuk validasi model.

2) Eksplorasi data 
a) Penelitian terhadap data beras diawali dengan melihat korelasi spasial menggunakan Indeks Moran, plot pencaran moran, dan uji otokorelasi spasial. Uji tersebut memiliki hipotesis $H_{0}$ yaitu tidak ada ketergantungan spasial dan $H_{1}$ yaitu ada ketergantungan spasial. Hipotesis nol ditolak jika nilai statistik uji lebih besar dari nilai kritis atau nilai$p$ lebih kecil dari alpha (0.05). Rentang nilai dari Indeks Moran adalah $-1 \leq$ $\mathrm{I} \leq 1$. Nilai $-1 \leq \mathrm{I}<0$ menunjukkan adanya ketergantungan spasial negatif, sedangkan nilai $0<\mathrm{I} \leq$ 1 menunjukkan adanya ketergantungan spasial positif, nilai Indeks Moran bernilai nol mengindikasikan tidak terdapat ketergantungan spasial (Yuriantari et al. (2017)).

b) Melakukan eksplorasi dengan melihat plot data untuk melihat gambaran secara umum tentang statistik deskriptif data harga beras di setiap provinsi dari tahun 2010 hingga 2017.

3) Memeriksa kestasioneran data

a) Untuk memeriksa kestasioneran terhadap ragam dapat dilihat dari plot data harga beras di setiap provinsi dan jika tidak stasioner dalam ragam, dilakukan tranformasi.

b) Untuk memeriksa kestasioneran terhadap rataan, dapat dilihat dari plot data harga beras di setiap provinsi dan dilihat dari hasil uji formal (Augmented Dickey Fuller) (ADF). Uji ADF mempunyai hipotesis $H_{0}$ yaitu data mengandung akar unit dan $H_{1}$ yaitu data tidak mengandung akar unit (Wei (2015)). Hipotesis nol ditolak jika nilai statistik ADF lebih besar dari nilai kritis atau nilai- $p$ lebih kecil dari alpha (0.05). Jika data belum stasioner dalam rataan, perlu dilakukan pembedaan (differencing).

4) Pembentukan model GSTARIMA

a) Mengidentifikasi ordo model GSTARIMA $(p, 1, q)$ dengan pendekatan VARIMA $(p, d, q)$ dengan $p$ adalah ordo model autoregressive, $\mathrm{d}$ adalah ordo pembedaan, q adalah ordo model moving average, dan nilai 1 merupakan ordo spasial. Mengidentifikasi VARIMA (p,d,q) dengan melihat lag MACF dan MPACF yang nyata. Selain itu, penentuan ordo GSTARIMA dihitung dari nilai AICC yang paling kecil.

b) Menentukan matriks pembobot kebalikan jarak dan melakukan pemodelan GSTARIMA. Bobot kebalikan jarak didapatkan dari penghitungan berdasarkan jarak sebenarnya antar lokasi. Lokasi yang berdekatan mendapatkan nilai bobot yang lebih besar dan lokasi yang berjauhan mendapatkan nilai bobot yang lebih kecil (Faizah and Setiawan (2013)).

c) Menentukan matriks pembobot queen contiguity sesuai dengan denah posisi setiap provinsi di Pulau Sumatera pada Gambar 1. Pembobot queen contiguity merupakan pembobot spasial yang di peroleh berdasarkan informasi ketetanggaan. Diagonal dari matriks ini umumnya diisi dengan nilai nol. Karena matriks pembobot menunjukkan hubungan antara keseluruhan observasi, dimensi dari matriks ini adalah nxn dengan $\mathrm{n}$ adalah banyaknya observasi atau banyaknya observasi lintas individu (Wijaya (2015)).

Berikut merupakan matriks pembobot queen contiguity berdasarkan Gambar 1, dengan baris dan kolom pertama adalah Z1 (Aceh) sampai baris dan kolom kesepuluh adalah Z10 (Kepri). Pertemuan antara kolom dan baris menunjukkan informasi ketetanggaan. Sebagai contoh, pertemuan antara baris kedua yaitu Z2 (Sumut) dengan kolom pertama yaitu Z1 (Aceh) menunjukkan bahwa Z2 (Sumut) memiliki tetangga langsung dengan Z1 (Aceh). Dua provinsi yang terpisah oleh lautan yaitu Babel dan Kepri, dianggap memiliki tetangga langsung. Provinsi Babel dianggap bertetanggan langsung 


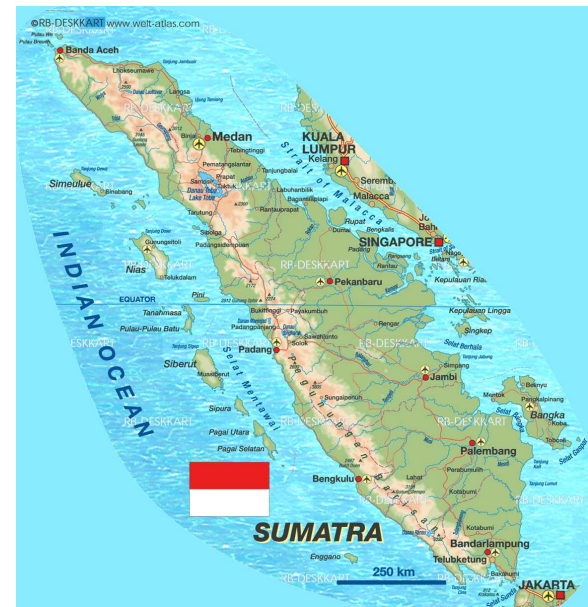

Gambar 1. Peta ibukota provinsi di Pulau Sumatera

dengan Provinsi Sumsel dan Provinsi Kepri dianggap bertetanggan langsung dengan Provinsi Riau.

$$
\left(\begin{array}{cccccccccc}
0 & 1 & 0 & 0 & 0 & 0 & 0 & 0 & 0 & 0 \\
\frac{1}{3} & 0 & \frac{1}{3} & \frac{1}{3} & 0 & 0 & 0 & 0 & 0 & 0 \\
0 & \frac{1}{3} & 0 & \frac{1}{3} & \frac{1}{3} & 0 & 0 & 0 & 0 & 0 \\
0 & \frac{1}{4} & \frac{1}{4} & 0 & \frac{1}{4} & 0 & 0 & 0 & 0 & \frac{1}{4} \\
0 & 0 & \frac{1}{4} & \frac{1}{4} & 0 & \frac{1}{4} & \frac{1}{4} & 0 & 0 & 0 \\
0 & 0 & 0 & 0 & \frac{1}{4} & 0 & \frac{1}{4} & \frac{1}{4} & \frac{1}{4} & 0 \\
0 & 0 & 0 & 0 & \frac{1}{2} & \frac{1}{2} & 0 & 0 & 0 & 0 \\
0 & 0 & 0 & 0 & 0 & 1 & 0 & 0 & 0 & 0 \\
0 & 0 & 0 & 0 & 0 & 1 & 0 & 0 & 0 & 0 \\
0 & 0 & 0 & 1 & 0 & 0 & 0 & 0 & 0 & 0
\end{array}\right)
$$

Selanjutnya melakukan pemodelan GSTARIMA.

d) Pendugaan parameter model GSTARIMA setiap provinsi di Pulau Sumatera untuk bobot kebalikan jarak dan bobot queen contiguity menggunakan metode kuadrat terkecil. Model persamaan yang akan terbentuk sebanyak 10 model untuk masingmasing pembobot yang digunakan.

5) Pengujian asumsi sisaan

Melakukan uji asumsi sisaan dari model yang diperoleh untuk masing-masing pembobot lokasi. Asumsi sisaan yang dipenuhi dalam pengujian ini adalah white noise yaitu kenormalan sisaan dan kebebasan ragam sisaan.

a) Uji kenormalan sisaan secara eksploratif dapat dilihat dari histogram sisaan dan secara uji formal menggunakan uji Jarque Bera.

b) Uji kebebasan sisaan secara sendirisendiri menggunakan uji Box-Pierce dan uji kebebasan sisaan secara simultan menggunakan plot MACF sisaan.

6) Validasi model dan kesimpulan

Langkah selanjutnya adalah validasi model. Model terbaik menggunakan nilai MAPE terkecil dari model yang dihasilkan.

\section{HASIL DAN PEMBAHASAN}

\section{A. Deskriptif Data}

Data harga beras di Pulau Sumatera diperoleh sebanyak 433 data dalam mingguan. Ada sebanyak 421 data digunakan untuk pendugaan model yaitu dari minggu pertama bulan Januari 2010 sampai minggu keempat bulan September 2017, sedangkan sebanyak 12 data untuk validasi model yaitu dari minggu pertama bulan Oktober 2017 hingga minggu terakhir bulan Desember 2017. Korelasi harga beras antar provinsi di Pulau Sumatera cukup tinggi, yaitu rentang dari 0.5 sampai lebih dari 0.95 . Nilai korelasi tersebut menunjukkan harga beras antar ibukota provinsi memiliki kekuatan hubungan positif. Nilai korelasi tertinggi terjadi antara Provinsi Jambi dan Sumatera Selatan yaitu sebesar 0.947, sedangkan nilai korelasi terendah terjadi antara Provinsi Kepulaun Riau dan Aceh yaitu sebesar 0.527.

Korelasi yang cukup tinggi belum cukup membuktikan bahwa terdapat ketergantungan spasial antar ibukota provinsi. Oleh karena itu, perlu dilakukan penghitungan Indeks Moran dan uji otokorelasi spasial yang menunjukkan ada tidaknya ketergantungan spasial antar lokasi. Tabel 2 menunjukkan nilai Indeks Moran dan hasil uji otokorelasi spasial dengan pembobot queen contiguity bernilai positif yang berarti terdapat ketergantungan spasial positif dan nilai Indeks Moran dengan pembobot kebalikan jarak bernilai negatif yang berarti terdapat ketergantungan spasial negatif. Akan tetapi, nilai- $p$ dari Indeks Moran untuk masing-masing pembobot lebih 
besar dari alpha (0.05). Hal tersebut menunjukkan bahwa secara uji otokorelasi spasial tidak terdapat ketergantungan spasial.

Tabel II

NILAI INDEKS MORAN MASING-MASING PEMBOBOT UNTUK 10 PROVINSI

\begin{tabular}{lcc}
\hline Bobot & Nilai indeks moran & Nilai- $p$ \\
\hline Kebalikan jarak & -0.050 & 0.344 \\
Queen contiguity & 0.058 & 0.532 \\
\hline
\end{tabular}

Akan tetapi, ketika dua provinsi di Pulau Sumatera, yaitu Provinsi Kepulauan Riau dan Bangka Belitung tidak diikutsertakan ke dalam uji otokorelasi spasial, hasil pada Tabel 3 menunjukkan bahwa uji otokorelasi spasialnya signifikan yang ditandai dengan besarnya nilai- $p$ dari Indeks Moran lebih kecil dari alpha (0.05) untuk masing-masing pembobot. Hal tersebut mengindikasikan terdapat ketergantungan spasial positif antar kedelapan provinsi lainnya. Hasil yang didapatkan juga mengindikasikan kedua provinsi tersebut menyebabkan nilai Indeks Morannya relatif kecil serta hasil uji otokorelasi spasialnya tidak signifikan, karena kedua provinsi tersebut tidak satu daratan dengan delapan provinsi lainnya dan terpisah oleh lautan. Hal ini diperkuat dengan hasil plot pencaran moran dari harga beras untuk masing-masing pembobot. Plot pencaran moran menunjukkan harga beras di kedua provinsi tersebut memiliki autokorelasi spasial negatif, artinya lokasi yang berdekatan tidak mirip. Akan tetapi, dalam penelitian ini tetap mengikutsertakan kedua provinsi tersebut ke dalam model.

Tabel III

NILAI INDEKS MORAN MASING-MASING PEMBOBOT UNTUK 8 PROVINSI

\begin{tabular}{lcc}
\hline Bobot & Nilai indeks moran & Nilai- $p$ \\
\hline Kebalikan jarak & 0.052 & 0.026 \\
Queen contiguity & 0.426 & 0.043 \\
\hline
\end{tabular}

Statistik deskriptif lainnya dapat dilihat dari pola plot data harga beras seluruh provinsi di Pulau Sumatera.Sebagian besar plot data harga beras setiap provinsi di Pulau Sumatera memiliki pola trend naik kecuali Provinsi Riau.Salah satu plot data harga beras yang memiliki pola trend naik adalah Gambar 2 yang menunjukkan plot data harga beras di Provinsi Aceh dan Gambar 3 menunjukkan plot data harga beras di Provinsi Kepulauan Riau yang memiliki pola cenderung konstan pada awal tahun 2010 hingga pertengahan tahun 2015. Selanjutnya mengalami kenaikkan hingga akhir tahun 2017 seperti halnya provinsi lainnya. Pola tersebut mengindikasikan bahwa data harga beras tidak stasioner.

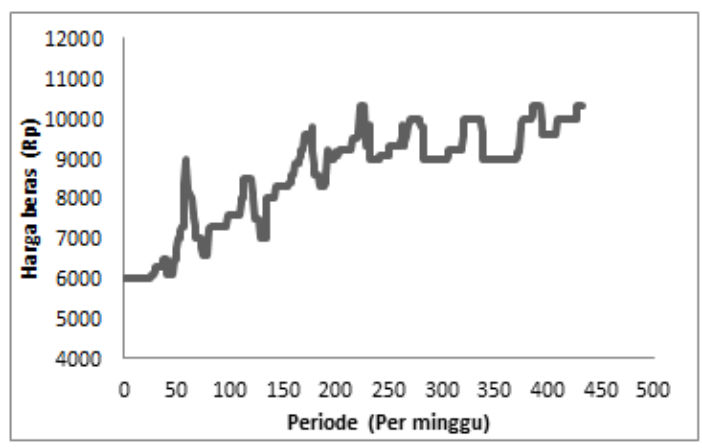

Gambar 2. Plot data harga beras per minggu di Provinsi Aceh

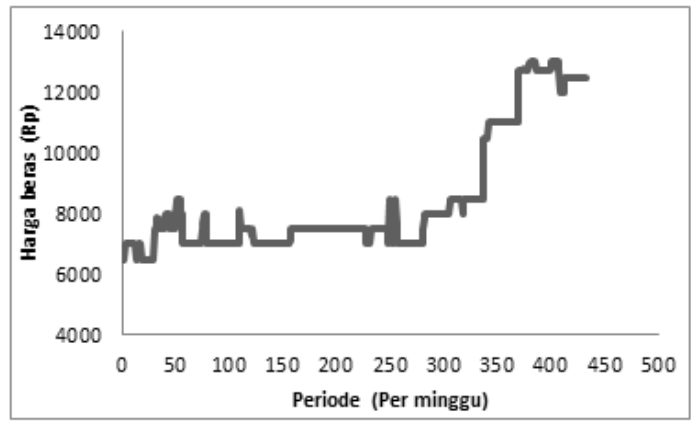

Gambar 3. Plot data harga beras per minggu di Provinsi Kepulauan Riau

Rata-rata harga beras tertinggi terjadi pada Provinsi Riau yaitu sebesar Rp10 399 serta memiliki harga maksimum sebesar Rp14 000 yang terjadi pada minggu pertama dan minggu kedua bulan November 2016 dan harga minimum sebesar Rp7 400 yang terjadi pada minggu pertama bulan Maret 2010. Rata-rata harga beras terendah terjadi pada provinsi Lampung dengan harga sebesar Rp8 046.9 dengan memiliki harga maksimum sebesar Rp10 320 yang terjadi pada minggu pertama bulan Maret 2015 dan harga minimum sebesar Rp5 500.0 yang terjadi pada minggu pertama dan minggu kedua bu- 
lan Januari 2010. Simpangan baku tertinggi terjadi pada Provinsi Kepulauan Riau yaitu sebesar Rp2 036.5 dan simpangan baku terendah terjadi pada Provinsi Lampung yaitu sebesar Rp930.3. Provinsi Riau merupakan provinsi yang memiliki harga beras tertinggi di Pulau Sumatera dengan harga sebesar Rp14 000.0 yang terjadi pada minggu pertama dan minggu kedua bulan November 2016 dan Provinsi Sumatera Selatan merupakan provinsi yang memiliki harga beras terendah di Pulau Sumatera dengan harga sebesar Rp5 400.0 yang terjadi pada minggu ketiga dan minggu keempat bulan Mei 2010.

\section{B. Kestasioneran Data}

Data harga beras dinyatakan stasioner jika telah stasioner dalam ragam dan rataan. Jika data belum stasioner terhadap ragam, perlu dilakukan transformasi, sedangkan jika data belum stasioner terhadap rataan, perlu dilakukan pembedaan (differencing). Plot data harga beras setiap provinsi di Pulau Sumatera belum stasioner terhadap ragam, sehingga perlu dilakukan transformasi dalam bentuk logaritma natural. Salah satu contoh plot yang tidak stasioner terhadap ragam adalah Gambar 4 yang menunjukkan plot harga beras hasil transformasi di Provinsi Aceh. Plot data harga beras setelah di transformasi belum stasioner terhadap rataan. Pemeriksaan stasioner terhadap rataan juga dapat dilakukan dengan menggunakan Uji Augmented Dickey-Fuller (ADF). Hasil uji ADF menunjukkan data harga beras yang telah ditransformasi belum seluruhnya stasioner terhadap rataan, karena nilai- $p$ hasil uji ADF di setiap provinsi masih terdapat nilai yang lebih besar dari alpha (0.05) yaitu Provinsi Jambi, Sumatera Selatan, Bangka Belitung, dan Kepulauan Riau.Perlu dilakukan pembedaan (differencing) sebanyak satu kali. Setelah dilakukan pembedaan, dilihat secara eksploratif dan secara uji formal menunjukkan data harga beras pada semua lokasi sudah stasioner dalam rataan. Gambar 5 menunjukkan salah satu plot data harga beras di salah satu provinsi setelah mengalami pembedaan yaitu Provinsi Aceh.

\section{Model GSTARIMA}

\section{Identifikasi Model}

Penentuan ordo waktu pada model GSTARIMA dapat diturunkan dari ordo model VARIMA. Identifikasi ordo model VARIMA dapat menggunakan

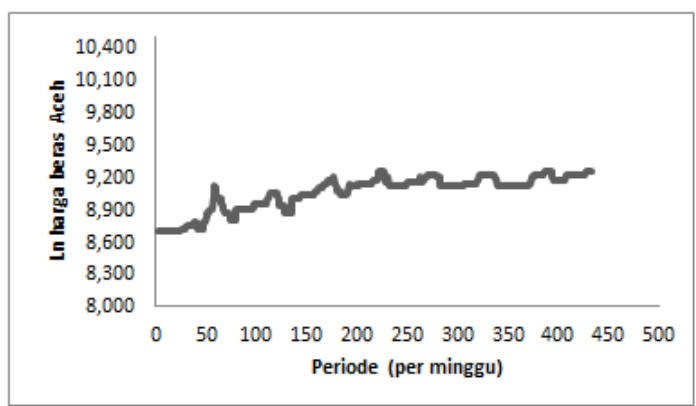

Gambar 4. Plot data harga beras dengan transfromasi logaritma natural di ibukota provinsi Aceh

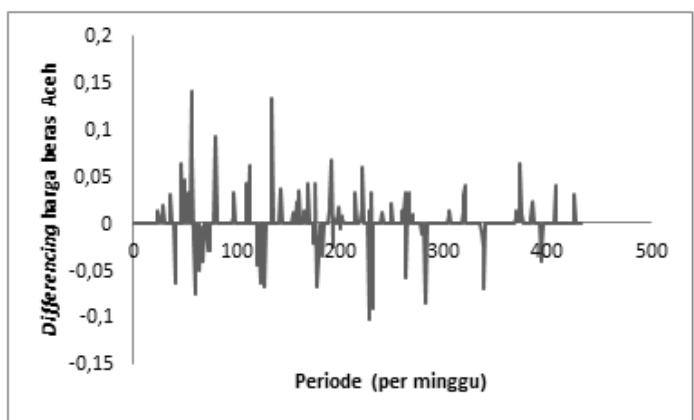

Gambar 5. Plot data differencing harga beras di ibukota provinsi Aceh

plot MACF dan MPACF serta nilai AICC terkecil yang dihasilkan. Penentuan ordo spasial pada umumnya menggunakan nilai 1 , karena untuk ordo yang lebih tinggi akan sulit diinterpretasikan (Setiawan 2015). Tabel 4 menunjukkan nilai-nilai AICC yang merupakan kombinasi semua model autoregressive (AR) dan moving average (MA) sampai lag ke-5. Model AR (1) merupakan model yang cocok karena memiliki nilai AICC terkecil yaitu sebesar -77.73, sehingga model yang terbentuk adalah VAR (1). Ordo yang diperoleh pada data ini yaitu ordo 1 untuk ordo spasial dan ordo 1 untuk ordo waktunya. Ordo untuk model GSTARIMA yang diperoleh adalah GSTARIMA $(1,1,0)$ atau bisa disebut juga model GSTARI $(1,1)$.

\section{Pembentukan Matriks Pembobot}

Penelitian ini menggunakan dua matriks pembobot yaitu pembobot kebalikan jarak dan queen contiguity. Bobot kebalikan jarak memberikan nilai bobot yang lebih besar untuk jarak yang lebih dekat dan memberikan nilai bobot yang kecil untuk jarak yang jauh. Jarak antar lokasi dihitung berdasarkan selisih 
Tabel IV

NILAI AICC DARI SEMUA MODEL TENTATIF

\begin{tabular}{rcccccc}
\hline Lag & MA0 & MA1 & MA2 & MA3 & MA4 & MA5 \\
\hline AR0 & -77.85 & -77.59 & -77.47 & -77.35 & -77.51 & -77.31 \\
AR1 & -77.79 & -77.47 & -77.36 & -77.27 & -77.37 & -77.16 \\
AR2 & -77.74 & -77.43 & -77.31 & -77.24 & -77.21 & -76.86 \\
AR3 & -77.56 & -77.29 & -77.22 & -76.94 & -76.85 & -76.49 \\
AR4 & -77.65 & -77.36 & -77.19 & -76.88 & -76.50 & -76.14 \\
AR5 & -77.42 & -77.32 & -76.93 & -76.59 & -76.16 & -75.78 \\
\hline
\end{tabular}

letak lintang dan bujur antar lokasi yang kemudian dikonversikan ke dalam jarak sebenarnya dalam satuan kilometer.

Pembobot queen contiguity memberikan nilai 1 jika lokasi-i bertetanggaan langsung dengan lokasi-j, sedangkan nilai 0 untuk lokasi-i yang tidak bertetanggaan langsung dengan lokasi-j. Matriks pembobot queen contiguity dihitung berdasarkan rasio antara nilai pada lokasi tertentu dengan jumlah tetangga langsung yang dimiliki lokasi oleh tersebut.

\section{Pendugaan Parameter Model GSTARIMA}

Model terbaik yang terpilih pada pemodelan harga beras untuk sepuluh ibukota provinsi di Pulau Sumatera adalah GSTARIMA $(1,1,0)$ atau bisa disebut juga model GSTARI $(1,1)$ yang memiliki ordo 1 untuk lag waktu dan ordo 1 untuk lag spasialnya. Persamaan umum model GSTARI $(1,1)$ adalah sebagai berikut :

$$
\nabla Z_{i}(t)=\sum_{k=1}^{1} \sum_{l=0}^{1} \phi_{k l}^{i} W^{(l)} \nabla Z_{i}(t-k)+\varepsilon_{t}
$$

$\nabla Z_{i}(t)=\phi_{10}^{i} W^{(0)} Z_{i}(t-1)+\phi_{11}^{i} W^{(1)} Z_{i}(t-1)+\varepsilon_{t}$

$Z_{i}(t)$ adalah vektor pengamatan yang sudah stasioner terhadap rataan dan ragam pada waktu ket, lokasi ke-i. $\phi_{k l}^{i}$ adalah matriks diagonal parameter autoregressive pada lag waktu ke-k dan lag spasial ke-1, berukuran 10x10 dengan diagonalnya $\phi_{k l}^{1}, \phi_{k l}^{2}, \ldots, \phi^{1} 0_{k l}$. $W^{(l)}$ adalah matriks pembobot spasial lag ke-l berukuran 10x10. $Z_{i}(t-k)$ adalah vektor pengamatan yang sudah stasioner terhadap rataan dan ragam pada waktu ke-t-k, lokasi ke-i. $\varepsilon_{t}$ adalah vektor sisaan berukuran 10x10.

Dari persamaan di atas, akan diduga $\phi_{10}^{i}$ dan $\phi_{11}^{i}$ untuk masing-masing provinsi di Pulau Sumatera. Pendugaan parameter pada masing-masing model menggunakan metode kuadrat terkecil. Tabel 5 me- nunjukkan hasil pendugaan parameter setiap lokasi untuk model GSTARI $(1,1)$ dengan matriks pembobot kebalikan jarak. Ada sebanyak 20 parameter yang dihasilkan.

Tabel V

NILAI DUGAAN PARAMETER DENGAN BOBOT KEBALIKAN JARAK

\begin{tabular}{cccc}
\hline Parameter & Nilai dugaan & Parameter & Nilai dugaan \\
\hline$\phi_{10}^{1}$ & 0.108926 & $\phi_{11}^{1}$ & 0.047469 \\
$\phi_{10}^{2}$ & 0.07013 & $\phi_{11}^{2}$ & 0.277478 \\
$\phi_{10}^{3}$ & 0.08329 & $\phi_{11}^{3}$ & 0.272199 \\
$\phi_{10}^{4}$ & 0.065134 & $\phi_{11}^{4}$ & 0.317208 \\
$\phi_{10}^{5}$ & 0.040267 & $\phi_{11}^{5}$ & 0.146476 \\
$\phi_{10}^{6}$ & 0.076256 & $\phi_{11}^{6}$ & -0.04499 \\
$\phi_{10}^{7}$ & 0.137183 & $\phi_{11}^{7}$ & 0.210127 \\
$\phi_{10}^{8}$ & 0.17994 & $\phi_{11}^{8}$ & 0.098426 \\
$\phi_{10}^{9}$ & -0.07674 & $\phi_{11}^{9}$ & 0.256208 \\
$\phi_{10}^{10}$ & -0.11581 & $\phi_{11}^{10}$ & 0.033016 \\
\hline
\end{tabular}

Sebagai contoh model persamaan GSTARI $(1,1)$ untuk Provinsi Aceh adalah sebagai berikut :

$\nabla Z_{1}(t)=0.108926 \nabla Z_{1}(t-1)+0.012199 \nabla$ $Z_{2}(t-1)+0.00574 \nabla Z_{3}(t-1)+0.00591 \nabla$ $Z_{4}(t-1)+0.091 \nabla Z_{5}(t-1)+0.004319 \nabla$ $Z_{6}(t-1)+0.004035 \nabla Z_{7}(t-1)+0.00318 \nabla$ $Z_{8}(t-1)+0.00356 \nabla Z_{9}(t-1)+0.0046 \nabla Z_{1} 0(t-1)$

Interpretasi dari model GSTARI $(1,1)$ lokasi Aceh menyatakan bahwa harga beras di Provinsi Aceh dipengaruhi oleh korelasi diri harga beras pada periode satu minggu sebelumnya dengan efek sebesar 0.108926. Selain dipengaruhi oleh efek korelasi diri, model juga dipengaruhi oleh efek spasialnya. Harga beras di Provinsi Sumatera Utara pada periode satu minggu sebelumnya memberikan efek spasial terbesar dengan efek sebesar 0.012199, sedangkan efek spasial terkecil diberikan oleh harga beras di Provinsi Lampung pada periode satu minggu sebelumnya dengan efek sebesar 0.0046. Provinsi Sumatera Utara merupakan provinsi terdekat dengan Provinsi Aceh, sedangkan Provinsi Lampung merupakan provinsi terjauh dari Provinsi Aceh. Terlihat dari persamaan yang terbentuk bahwa semakin jauh jarak yang dihasilkan maka semakin kecil efek spasialnya. Hal ini sesuai dengan penyataan bahwa semakin dekat jarak antar lokasi maka akan memberikan efek spasial lebih besar dan semakin jauh jarak antar lokasi maka akan memberikan efek 
spasial lebih kecil.

Persamaan umum model GSTARIMA $(1,1,0)$ dengan matriks pembobot queen contiguity memiliki persamaan yang sama dengan persamaan umum model GSTARIMA $(1,1,0)$ dengan matriks pembobot kebalikan jarak. Perbedaannya pada nilai matriks pembobot spasial lag ke-1 yaitu nilai $W^{(1)}$ yang digunakan. Pendugaan parameter untuk model GSTARI $(1,1)$ dengan matriks pembobot queen contiguity ditunjukkan oleh Tabel 6.

Tabel VI

NILAI DUGAAN PARAMETER DENGAN BOBOT QUEEN CONTIGUITY

\begin{tabular}{cccc}
\hline Parameter & Nilai dugaan & Parameter & Nilai dugaan \\
\hline$\phi_{10}^{1}$ & 0.081206 & $\phi_{11}^{1}$ & 0.177408 \\
$\phi_{10}^{2}$ & 0.050642 & $\phi_{11}^{2}$ & 0.209249 \\
$\phi_{10}^{3}$ & 0.078992 & $\phi_{11}^{3}$ & 0.261807 \\
$\phi_{10}^{4}$ & 0.06865 & $\phi_{11}^{4}$ & 0.272262 \\
$\phi_{10}^{5}$ & 0.040318 & $\phi_{11}^{5}$ & 0.093844 \\
$\phi_{10}^{6}$ & 0.076265 & $\phi_{11}^{6}$ & -0.03791 \\
$\phi_{10}^{7}$ & 0.147649 & $\phi_{11}^{7}$ & 0.078406 \\
$\phi_{10}^{8}$ & 0.191114 & $\phi_{11}^{8}$ & 0.005832 \\
$\phi_{10}^{9}$ & -0.06484 & $\phi_{11}^{9}$ & 0.039178 \\
$\phi_{10}^{10}$ & -0.11551 & $\phi_{11}^{10}$ & -0.00406 \\
\hline
\end{tabular}

Contoh model persamaan GSTARI $(1,1)$ untuk Provinsi Aceh adalah sebagai berikut :

$\nabla Z_{1}(t)=0.081206 \nabla Z_{1}(t-1)+0.177408 \nabla$ $Z_{2}(t-1)$

Interpretasi dari model GSTARI (1,1) untuk lokasi Aceh dengan menggunakan pembobot queen contiguity menyatakan bahwa harga beras Provinsi Aceh periode sekarang dipengaruhi oleh korelasi diri harga beras pada periode satu minggu sebelumnya dengan efek sebesar 0.081206. Provinsi Aceh hanya memiliki satu tetangga terdekat langsung yaitu Provinsi Sumatera Utara, sehingga pengaruh efek spasialnya hanya dipengaruhi oleh harga beras Provinsi Sumatera Utara pada periode satu minggu sebelumnya dengan efek sebesar 0.177408 .

\section{Pengujian Asumsi Sisaan}

Sisaan yang dihasilkan harus memenuhi asumsi sisaan white noise yaitu kebebasan sisaan dan kenormalan sisaan. Pemeriksaan kebebasan sisaan secara simultan dapat dilihat dari skema plot MACF sisaan.
Hasil menunjukkan bahwa tanda titik (.) pada skema plot sisaan lebih dominan daripada tanda (+) dan (-) yang berarti sisaan sudah saling bebas untuk masing-masing pembobot.

Uji kebebasan sisaan secara sendiri-sendiri menggunakan uji Box-Pierce. Hasil uji menunjukkan sisaan sudah saling bebas yang ditandai dengan besarnya nilai- $p$ lebih besar dari alpha (0.05). Uji kenormalan sisaan dapat dilihat dari histogram sisaan dan uji Jarque Bera. Histogram sisaan dari masing-masing pembobot cenderung simetris, namun hasil uji Jarque Bera memberikan kesimpulan bahwa secara formal sisaan tidak menyebar normal. Ketidaknormalan sisaan ini tidak mempengaruhi pendugaan parameter dan pendugaan kuadrat terkecil tetap menjadi pendugaan linier tak bias terbaik, sehingga tidak menjadi suatu permasalahan yang berarti.

\section{E. Pemilihan Model GSTARIMA Terbaik}

Model terbaik yang terpilih adalah model dengan nilai MAPE terkecil dari hasil ramalan. Ramalan yang dihasilkan berasal dari model GSTARI $(1,1)$ dengan semua parameter yang diduga dimasukkan ke dalam model untuk masing-masing pembobot. Tabel 7 menunjukkan hasil perbandingan nilai MAPE untuk setiap pembobot yang digunakan.

Tabel VII

PERBANDINGAN NILAI MAPE UNTUK MASING-MASING PEMBOBOT

\begin{tabular}{lcc}
\hline Lokasi & $\begin{array}{c}\text { MAPE } \\
\text { kebalikan jarak (\%) }\end{array}$ & $\begin{array}{c}\text { MAPE } \\
\text { queen contiguity (\%) }\end{array}$ \\
\hline Aceh & 1.45638 & 1.45622 \\
Sumut & 0.60512 & 0.49722 \\
Sumbar & 0.19110 & 0.01527 \\
Riau & 0.28722 & 0.27147 \\
Jambi & 5.06052 & 5.05409 \\
Sumsel & 2.73264 & 2.73212 \\
Bengkulu & 0.27401 & 0.27904 \\
Lampung & 0.34776 & 0.42980 \\
Babel & 1.21579 & 1.04636 \\
Kepri & 0.02395 & 0.00004 \\
\hline Rata-rata & 1.21945 & 1.17817 \\
\hline
\end{tabular}

Hasil menunjukkan bahwa rata-rata nilai MAPE terkecil adalah model GSTARI $(1,1)$ dengan menggunakan pembobot queen contiguity. Oleh karena itu, dapat disimpulkan bahwa model terbaik yang 
terpilih adalah model GSTARI $(1,1)$ dengan pembobot queen contiguity. Plot data ramalan pada masing-masing model mendekati data aktualnya. Hal tersebut menandakan bahwa model yang terpilih sudah cukup baik.

\section{SIMPULAN DAN SARAN}

\section{A. Simpulan}

Model GSTARIMA terbaik untuk harga beras setiap Provinsi di Pulau Sumatera adalah GSTARIMA $(1,1,0)$ atau bisa disebut GSTARI $(1,1)$ dengan matriks pembobot queen contiguity. Model peramalan harga beras di Pulau Sumatera adalah $\nabla Z_{i}(t)=$ $\phi_{10}^{i} W^{(0)} Z_{i}(t-1)+\phi_{11}^{i} W^{(1)} Z_{i}(t-1)+\varepsilon_{t}$.Peramalan harga beras untuk 12 minggu kedepan yaitu dari minggu pertama bulan Oktober 2017 hingga bulan Desember 2017 tidak jauh berbeda dengan harga beras aktualnya.

\section{B. Saran}

Nilai peluang Indeks Moran yang dihasilkan oleh matriks pembobot tidak signifikan pada taraf nyata (0.05) dan besarnya nilai Indeks Moran sangat kecil. Hal ini diindikasikan karena terdapat dua provinsi yang terpisah oleh lautan, tidak satu daratan dengan delapan provinsi lainnya yaitu Provinsi Bangka Belitung dan Provinsi Kepulauan Riau. Perlu dikaji lebih lanjut terkait penentuan matriks pembobot yang digunakan jika terdapat wilayah yang terpisah oleh lautan, tidak dalam satu daratan. Penelitian selanjutnya bisa dicoba dengan menggunakan matriks pembobot lain yang lebih cocok, misalnya matriks pembobot normalisasi korelasi silang yang dalam penentuannya tidak dipengaruhi secara langsung oleh jarak antar lokasi, namun hanya mengandalkan pada hubungan korelasi antar lokasi pada lag waktu tertentu.

\section{DAFTAR PUSTAKA}

BPS (2017). Statistik Indonesia 2017. Jakarta: Badan Pusat Statistik.

Daraputri, S. (2015). Penerapan Model Generalized Space Time pada Data Harga Gula Pasir di Pulau Jawa [Skripsi]. Bogor: Program Sarjana Institut Pertanian Bogor.

Faizah, L. and Setiawan (2013). Pemodelan inflasi di kota semarang, yogyakarta, dan surakarta dengan pendekatan gstar. Jurnal Sains dan Seni Pomits 2(2), 2337-3520.

Min, X., J. Hu, and Z. Zhang (2010, September). Urban traffic network modeling and shortterm traffic flow forecasting based on gstarima model. In Proceedings of13th International IEEE, Annual Conference on Intelligent Transportation Systems.

Muljawan, R. and R. Alibaba (2009). Faktor-faktor yang mempengaruhi harga beras di jawa timur. Buana Sains 9(2), 111-118.

Noviar, H. (2013). Analisi kecukupan dan ketersediaan beras di indonesia (1975-2009). Jurnal Penelitien llmu-ilmu Sosial (7), 93.

Pfeifer, P. and S. Deutsch (1980). A three stage iterative procedure for space-time modeling. Technometrics 22(1), 35-47.

Siregar, D. (2015). Perbandingan Pemodelan dan Peramalan Harga Gula berdasarkan Model STARIMA dan GSTARIMA [Tesis]. Bogor: Program Pascasarjana Institut Pertanian Bogor.

Wei, W. (2015). Time Series Analysis: Univariate and Multivariate Methods Second Edition. New York: Addison-Wesley Publishing Co.

Wijaya, F. (2015). Pendekatan Space Time Autoregressive (STAR) dan Generalized Space Time Autoregeressive (GSTAR) Melalui Metode Autoregressive (AR) dan Vector Autoregressive (VAR) [Tesis]. Bogor: Program Pascasarjana Institut Pertanian Bogor.

Yuriantari, N., M. Hayati, and S. Wahyuningsih (2017). Analisis autokorelasi spasial titik panas di kalimantan timur menggunakan indeks moran dan local indicator of spatial autocorrelation (lisa). Jurnal Exponensial (8), 63-69.

Yusrina, F., I. Sumertajaya, and B. Susetyo (2017). Model Peramalan Harga Beras dengan Pendekatan Generalized Space Time (Studi Kasus Provinsi DKI Jakarta, Jawa Barat, dan Banten) [Tesis]. Bogor: Program Pascasarjana Institut Pertanian Bogor. 